\title{
New Steroids from the Soft Coral Nephthea chabrolii
}

\author{
Jui-Hsin Su, ${ }^{1}$ Fang-Yee Lin, ${ }^{1}$ Chang-Feng Dai, ${ }^{2}$ Yang-Chang Wu, ${ }^{3}$ \\ Chi-Hsin Hsu, ${ }^{1,4}$ and Jyh-Horng Sheu*1,4
}

\author{
${ }^{1}$ Department of Marine Biotechnology and Resources, National Sun Yat-sen University, Kaohsiung 804, Taiwan \\ ${ }^{2}$ Institute of Oceanography, National Taiwan University, Taipei 112, Taiwan \\ ${ }^{3}$ Graduate Institute of Natural Products, Kaohsiung Medical University, Kaohsiung 807, Taiwan \\ ${ }^{4}$ Asian Pacific Ocean Research Center, National Sun Yat-sen University, Kaohsiung 804, Taiwan
}

Received May 23, 2007; E-mail: sheu@ mail.nsysu.edu.tw

Six new steroids, chabrolosteroids D-I (1-6), were isolated from the organic extract of a Taiwanese soft coral Nephthea chabrolii. The structures of these metabolites were determined on the basis of extensive spectroscopic analysis. Metabolite 6 was found to exhibit weak cytotoxicity against the growth of Hep 3B and A-549 cell lines.

In our previous studies, we have isolated from the soft coral Nephthea chabrolii Audouin (Alcyonacea, Nephthedae) 25 new natural products, including eighteen meroditerpenoids, ${ }^{1-3}$ three steroids, ${ }^{4}$ two $\mathrm{C}_{18}$ terpenoid-related carboxylic acids, ${ }^{3}$ and two sesquiterpenoids. ${ }^{3}$ During our continuing studies on the chemical constituents of $N$. chabrolii, six new steroids, chabrolosteroids D-I (1-6) (Chart 1), were isolated. We describe herein the isolation, structure elucidation, and biological activity of these new metabolites.

N. chabrolii was collected off the coast of Pingtung County, southern Taiwan, and extracted exhaustively with EtOH. After evaporation of the solvent, the residue of $\mathrm{EtOH}$ extract was triturated sequentially with $n$-hexane, and then with EtOAc. The EtOAc soluble part was subjected to Si gel column chromatography (CC) and eluted with solvent mixtures of increasing polarity. By the examination of the ${ }^{1} \mathrm{HNMR}$ spectra of the fractions eluted, two fractions containing steroids, as shown by the appearance of the signals of C-18 and C-19 methyl protons resonating at $0.74-1.23 \mathrm{ppm}$, were selected and further purified by normal phase HPLC to afford 1-6 (see Experimental section). All compounds were obtained as white powders.

Chabrolosteroid D (1) was found to have a molecular formula of $\mathrm{C}_{28} \mathrm{H}_{42} \mathrm{O}_{4}$ on the basis of the HR-ESI-MS spectrum $\left(m / z 443.3158[\mathrm{M}+\mathrm{H}]^{+}\right)$and NMR spectra (Tables 1 and 2$)$. The IR spectrum of $\mathbf{1}$ showed absorption bands characteristic of hydroxy $\left(3366 \mathrm{~cm}^{-1}\right)$ and carbonyl $\left(1708\right.$ and $\left.1680 \mathrm{~cm}^{-1}\right)$ groups. The ${ }^{1} \mathrm{HNMR}$ spectral data (Table 1) of $\mathbf{1}$ showed the presence of one olefinic methine proton $(\delta 5.74, \mathrm{~s})$, two olefinic methylene protons ( $\delta 4.78$ and 4.71 , each s), one oxymethine proton $(\delta 4.14, \mathrm{t}, J=7.5 \mathrm{~Hz})$, and four methyls $(\delta$ 1.16 , s; $1.02, \mathrm{~d}, J=7.0 \mathrm{~Hz} ; 1.01, \mathrm{~d}, J=7.0 \mathrm{~Hz} ; 0.78, \mathrm{~s})$. The ${ }^{13} \mathrm{CNMR}$ data (Table 2) of $\mathbf{1}$ showed the presence of twentyeight carbon signals, which were assigned with the aid of DEPT spectra as four methyls, nine $\mathrm{sp}^{3}$ methylenes, one $\mathrm{sp}^{2}$ methylene, seven $\mathrm{sp}^{3}$ methines (including one oxygenated), one $\mathrm{sp}^{2}$ methine, and two $\mathrm{sp}^{3}$ and four $\mathrm{sp}^{2}$ quaternary carbons. Above observations together with the NMR signals appearing

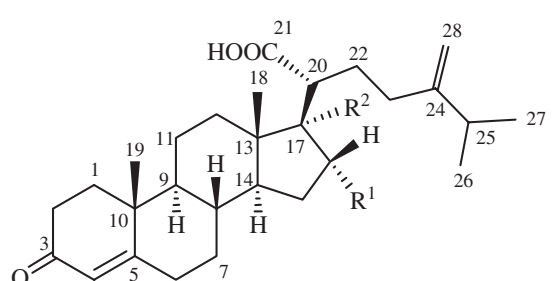

$1: \mathrm{R}^{1}=\mathrm{OH}, \mathrm{R}^{2}=\mathrm{H}$

2: $\mathrm{R}^{1}=\mathrm{H}, \mathrm{R}^{2}=\mathrm{H}$

$3: \mathrm{R}^{1}=\mathrm{H}, \mathrm{R}^{2}=\mathrm{OH}$

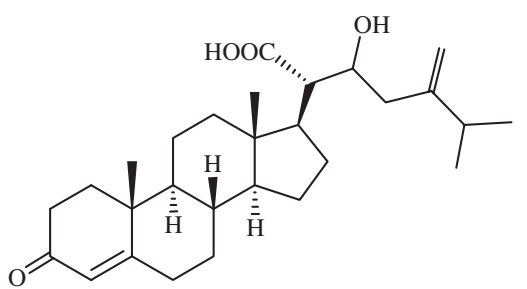

4

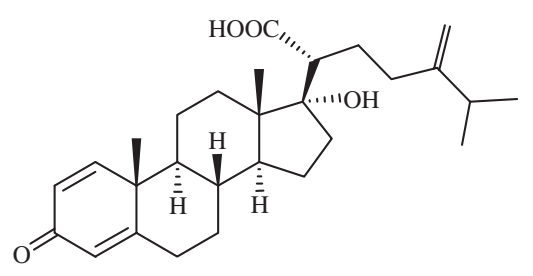

5

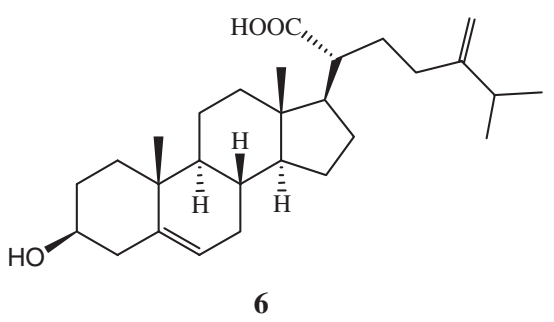

Chart 1 
Table 1. ${ }^{1}$ H NMR Chemical Shifts for Compounds 1-6

\begin{tabular}{|c|c|c|c|c|c|c|}
\hline No. & $1^{\text {a) }}$ & $2^{\mathrm{b})}$ & $3^{\text {a) }}$ & $4^{\text {a) }}$ & $5^{\text {a) }}$ & $6^{\text {a) }}$ \\
\hline 1 & $\alpha: 1.65 \mathrm{~m} ; \beta: 1.97 \mathrm{~m}$ & $\alpha: 1.67 \mathrm{~m} ; \beta: 1.99 \mathrm{~m}$ & $\alpha: 1.67 \mathrm{~m} ; \beta: 1.97 \mathrm{~m}$ & $\alpha: 1.68 \mathrm{~m} ; \beta: 2.00 \mathrm{~m}$ & $7.04 \mathrm{~d}(10.0)$ & $\alpha: 1.09 \mathrm{~m} ; \beta: 1.79 \mathrm{~m}$ \\
\hline 2 & $\alpha: 2.41 \mathrm{~m} ; \beta: 2.34 \mathrm{~m}$ & $2.40 \mathrm{~m}$ & $\alpha: 2.35 \mathrm{~m} ; \beta: 2.41 \mathrm{~m}$ & $\alpha: 2.34 \mathrm{~m} ; \beta: 2.40 \mathrm{~m}$ & $6.24 \mathrm{~d}(10.0)$ & $1.67 \mathrm{~m}$ \\
\hline 3 & & & & & & $3.51 \mathrm{~m}$ \\
\hline 4 & $5.74 \mathrm{~s}$ & $5.73 \mathrm{~s}$ & $5.74 \mathrm{~s}$ & $5.74 \mathrm{~s}$ & $6.10 \mathrm{~s}$ & $\alpha: 2.29 \mathrm{~m} ; \beta: 2.22 \mathrm{~m}$ \\
\hline \multirow[t]{2}{*}{6} & $\alpha: 2.27 \mathrm{~m}$ & $2.29 \mathrm{~m}$ & $\alpha: 2.27 \mathrm{~m}$ & $\alpha: 2.27 \mathrm{~m}$ & $\alpha: 2.37 \mathrm{dt}(12.0,2.5)$ & $5.34 \mathrm{~d}(4.5)$ \\
\hline & $\beta: 2.37 \mathrm{~m}$ & & $\beta: 2.38 \mathrm{~m}$ & $\beta: 2.37 \mathrm{~m}$ & $\begin{array}{l}\beta: 2.47 \mathrm{ddd} \\
(13.5,12.0,5.5)\end{array}$ & \\
\hline 7 & $\alpha: 1.07 \mathrm{~m} ; \beta: 1.81 \mathrm{~m}$ & $\alpha: 1.08 \mathrm{~m} ; \beta: 1.86 \mathrm{~m}$ & $\alpha: 1.08 \mathrm{~m} ; \beta: 1.84 \mathrm{~m}$ & $\alpha: 1.06 \mathrm{~m} ; \beta: 1.84 \mathrm{~m}$ & $\alpha: 1.94 \mathrm{~m} ; \beta: 1.06 \mathrm{~m}$ & $1.82 \mathrm{~m}$ \\
\hline 8 & $1.52 \mathrm{~m}$ & $1.59 \mathrm{~m}$ & $1.56 \mathrm{~m}$ & $1.55 \mathrm{~m}$ & $1.80 \mathrm{~m}$ & $1.54 \mathrm{~m}$ \\
\hline 9 & $0.98 \mathrm{~m}$ & $0.96 \mathrm{~m}$ & $0.95 \mathrm{~m}$ & $0.95 \mathrm{~m}$ & $1.06 \mathrm{~m}$ & $0.92 \mathrm{~m}$ \\
\hline 11 & $\alpha: 1.49 \mathrm{~m} ; \beta: 1.37 \mathrm{~m}$ & $1.51 \mathrm{~m}$ & $1.54 \mathrm{~m}$ & $\alpha: 1.52 \mathrm{~m} ; \beta: 1.39 \mathrm{~m}$ & $1.62 \mathrm{~m}$ & $\alpha: 1.39 \mathrm{~m} ; \beta: 1.47 \mathrm{~m}$ \\
\hline 12 & $\alpha: 1.24 \mathrm{~m} ; \beta: 1.72 \mathrm{~m}$ & $1.76 \mathrm{~m}$ & $\alpha: 1.50 \mathrm{~m} ; \beta: 1.39 \mathrm{~m}$ & $\alpha: 1.12 \mathrm{~m} ; \beta: 1.84 \mathrm{~m}$ & $\alpha: 1.46 \mathrm{~m} ; \beta: 1.40 \mathrm{~m}$ & $1.71 \mathrm{~m}$ \\
\hline 14 & $1.44 \mathrm{~m}$ & $1.09 \mathrm{~m}$ & $1.74 \mathrm{~m}$ & $1.10 \mathrm{~m}$ & $1.73 \mathrm{~m}$ & $1.02 \mathrm{~m}$ \\
\hline 15 & $1.74 \mathrm{~m} ; 1.62 \mathrm{~m}$ & $1.68 \mathrm{~m} ; 1.14 \mathrm{~m}$ & $1.72 \mathrm{~m} ; 1.14 \mathrm{~m}$ & $1.70 \mathrm{~m} ; 1.18 \mathrm{~m}$ & $1.04 \mathrm{~m} ; 1.74 \mathrm{~m}$ & $1.67 \mathrm{~m} ; 1.12 \mathrm{~m}$ \\
\hline 16 & $4.14 \mathrm{t}(7.5)^{\mathrm{c})}$ & $1.90 \mathrm{~m} ; 1.32 \mathrm{~m}$ & $1.78 \mathrm{~m}$ & $2.06 \mathrm{~m} ; 1.38 \mathrm{~m}$ & $1.80 \mathrm{~m}$ & $1.89 \mathrm{~m} ; 1.30 \mathrm{~m}$ \\
\hline 17 & $1.64 \mathrm{~m}$ & $1.70 \mathrm{~m}$ & & $1.90 \mathrm{~m}$ & & $1.65 \mathrm{~m}$ \\
\hline 18 & $0.78 \mathrm{~s}$ & $0.77 \mathrm{~s}$ & $0.85 \mathrm{~s}$ & $0.81 \mathrm{~s}$ & $0.88 \mathrm{~s}$ & $0.74 \mathrm{~s}$ \\
\hline 19 & $1.16 \mathrm{~s}$ & $1.16 \mathrm{~s}$ & $1.17 \mathrm{~s}$ & $1.18 \mathrm{~s}$ & $1.23 \mathrm{~s}$ & $0.99 \mathrm{~s}$ \\
\hline 20 & $2.48 \mathrm{~m}$ & $2.31 \mathrm{~m}$ & $2.59 \mathrm{~m}$ & $2.42 \mathrm{~m}$ & $2.63 \mathrm{~m}$ & $2.28 \mathrm{~m}$ \\
\hline \multicolumn{7}{|l|}{21} \\
\hline 22 & $1.81 \mathrm{~m} ; 1.94 \mathrm{~m}$ & $1.72 \mathrm{~m}$ & $1.77 \mathrm{~m} ; 1.98 \mathrm{~m}$ & 3.89 br s & $1.78 \mathrm{~m} ; 1.97 \mathrm{~m}$ & $1.98 \mathrm{~m}$ \\
\hline 23 & $2.07 \mathrm{~m} ; 2.00 \mathrm{~m}$ & $2.01 \mathrm{~m}$ & $2.00 \mathrm{~m}$ & $2.29 \mathrm{~m} ; 2.24 \mathrm{~m}$ & $2.02 \mathrm{~m} ; 2.06 \mathrm{~m}$ & $1.50 \mathrm{~m}$ \\
\hline \multicolumn{7}{|l|}{24} \\
\hline 25 & $2.22 \mathrm{~m}$ & $2.24 \mathrm{~m}$ & $2.21 \mathrm{~m}$ & $2.22 \mathrm{~m}$ & $2.22 \mathrm{~m}$ & $2.20 \mathrm{~m}$ \\
\hline 26 & $1.02 \mathrm{~d}(7.0)$ & $1.01 \mathrm{~d}(6.7)$ & $1.01 \mathrm{~d}(7.0)$ & $1.04 \mathrm{~d}(7.0)$ & $1.03 \mathrm{~d}(7.0)$ & $1.01 \mathrm{~d}(6.5)$ \\
\hline 27 & $1.01 \mathrm{~d}(7.0)$ & $1.00 \mathrm{~d}(6.7)$ & $1.02 \mathrm{~d}(7.0)$ & $1.06 \mathrm{~d}(7.0)$ & $1.01 \mathrm{~d}(7.0)$ & $1.00 \mathrm{~d}(7.0)$ \\
\hline 28 & $4.78 \mathrm{~s} ; 4.71 \mathrm{~s}$ & $4.67 \mathrm{~s} ; 4.76 \mathrm{~s}$ & $4.71 \mathrm{~s} ; 4.78 \mathrm{~s}$ & $4.97 \mathrm{~s} ; 4.83 \mathrm{~s}$ & $4.78 \mathrm{~s} ; 4.71 \mathrm{~s}$ & $4.67 \mathrm{~s} ; 4.75 \mathrm{~s}$ \\
\hline
\end{tabular}

a) Spectra recorded at $500 \mathrm{MHz}$ in $\mathrm{CDCl}_{3}$. b) $300 \mathrm{MHz}$ in $\mathrm{CDCl}_{3}$. c) $J$ values (in $\mathrm{Hz}$ ) parenthese.

Table 2. ${ }^{13} \mathrm{C}$ NMR Chemical Shifts for Compounds 1-6

\begin{tabular}{|c|c|c|c|c|c|c|c|c|c|c|c|c|}
\hline \multirow{2}{*}{$\begin{array}{c}\text { No. } \\
1\end{array}$} & \multicolumn{2}{|c|}{$1^{\text {a) }}$} & \multicolumn{2}{|c|}{$2^{\mathrm{b})}$} & \multicolumn{2}{|c|}{$3^{\text {a) }}$} & \multicolumn{2}{|c|}{$4^{\text {a) }}$} & \multicolumn{2}{|c|}{$5^{\text {a) }}$} & \multicolumn{2}{|c|}{$6^{\text {a) }}$} \\
\hline & 35.6 & $\left.\left(\mathrm{CH}_{2}\right)^{\mathrm{c}}\right)$ & 35.8 & $\left(\mathrm{CH}_{2}\right)$ & 35.7 & $\left(\mathrm{CH}_{2}\right)$ & 35.7 & $\left(\mathrm{CH}_{2}\right)$ & 151.6 & $(\mathrm{CH})$ & 37.3 & $\left(\mathrm{CH}_{2}\right)$ \\
\hline 2 & 33.9 & $\left(\mathrm{CH}_{2}\right)$ & 34.0 & $\left(\mathrm{CH}_{2}\right)$ & 33.8 & $\left(\mathrm{CH}_{2}\right)$ & 33.9 & $\left(\mathrm{CH}_{2}\right)$ & 127.4 & $(\mathrm{CH})$ & 30.6 & $\left(\mathrm{CH}_{2}\right)$ \\
\hline 3 & 199.5 & (C) & 199.7 & (C) & 199.8 & (C) & 199.8 & (C) & 186.6 & (C) & 71.7 & $(\mathrm{CH})$ \\
\hline 4 & 124.0 & $(\mathrm{CH})$ & 123.9 & $(\mathrm{CH})$ & 123.8 & $(\mathrm{CH})$ & 123.8 & $(\mathrm{CH})$ & 123.8 & $(\mathrm{CH})$ & 42.2 & $\left(\mathrm{CH}_{2}\right)$ \\
\hline 5 & 171.0 & (C) & 171.5 & (C) & 171.7 & (C) & 171.5 & (C) & 169.7 & (C) & 140.7 & (C) \\
\hline 6 & 32.7 & $\left(\mathrm{CH}_{2}\right)$ & 32.9 & $\left(\mathrm{CH}_{2}\right)$ & 32.9 & $\left(\mathrm{CH}_{2}\right)$ & 32.8 & $\left(\mathrm{CH}_{2}\right)$ & 32.9 & $\left(\mathrm{CH}_{2}\right)$ & 121.5 & $(\mathrm{CH})$ \\
\hline 7 & 31.8 & $\left(\mathrm{CH}_{2}\right)$ & 32.0 & $\left(\mathrm{CH}_{2}\right)$ & 31.9 & $\left(\mathrm{CH}_{2}\right)$ & 31.9 & $\left(\mathrm{CH}_{2}\right)$ & 33.6 & $\left(\mathrm{CH}_{2}\right)$ & 31.6 & $\left(\mathrm{CH}_{2}\right)$ \\
\hline 8 & 34.9 & $(\mathrm{CH})$ & 35.6 & $(\mathrm{CH})$ & 35.7 & $(\mathrm{CH})$ & 35.6 & $(\mathrm{CH})$ & 35.6 & $(\mathrm{CH})$ & 31.8 & $(\mathrm{CH})$ \\
\hline 9 & 53.5 & $(\mathrm{CH})$ & 53.8 & $(\mathrm{CH})$ & 53.3 & $(\mathrm{CH})$ & 53.8 & $(\mathrm{CH})$ & 51.8 & $(\mathrm{CH})$ & 50.1 & $(\mathrm{CH})$ \\
\hline 10 & 38.5 & (C) & 38.6 & (C) & 38.5 & (C) & 38.6 & (C) & 43.6 & (C) & 36.5 & (C) \\
\hline 11 & 20.5 & $\left(\mathrm{CH}_{2}\right)$ & 21.0 & $\left(\mathrm{CH}_{2}\right)$ & 20.8 & $\left(\mathrm{CH}_{2}\right)$ & 20.8 & $\left(\mathrm{CH}_{2}\right)$ & 22.6 & $\left(\mathrm{CH}_{2}\right)$ & 21.0 & $\left(\mathrm{CH}_{2}\right)$ \\
\hline 12 & 37.5 & $\left(\mathrm{CH}_{2}\right)$ & 37.4 & $\left(\mathrm{CH}_{2}\right)$ & 30.6 & $\left(\mathrm{CH}_{2}\right)$ & 36.9 & $\left(\mathrm{CH}_{2}\right)$ & 30.5 & $\left(\mathrm{CH}_{2}\right)$ & 37.4 & $\left(\mathrm{CH}_{2}\right)$ \\
\hline 13 & 43.8 & (C) & 42.2 & (C) & 47.5 & (C) & 43.8 & (C) & 47.7 & (C) & 42.0 & (C) \\
\hline 14 & 52.3 & $(\mathrm{CH})$ & 55.4 & $(\mathrm{CH})$ & 49.3 & $(\mathrm{CH})$ & 55.4 & $(\mathrm{CH})$ & 48.9 & $(\mathrm{CH})$ & 56.1 & $(\mathrm{CH})$ \\
\hline 15 & 36.5 & $\left(\mathrm{CH}_{2}\right)$ & 23.6 & $\left(\mathrm{CH}_{2}\right)$ & 22.9 & $\left(\mathrm{CH}_{2}\right)$ & 23.4 & $\left(\mathrm{CH}_{2}\right)$ & 23.1 & $\left(\mathrm{CH}_{2}\right)$ & 23.7 & $\left(\mathrm{CH}_{2}\right)$ \\
\hline 16 & 75.8 & $(\mathrm{CH})$ & 27.2 & $\left(\mathrm{CH}_{2}\right)$ & 36.0 & $\left(\mathrm{CH}_{2}\right)$ & 26.9 & $\left(\mathrm{CH}_{2}\right)$ & 36.1 & $\left(\mathrm{CH}_{2}\right)$ & 27.1 & $\left(\mathrm{CH}_{2}\right)$ \\
\hline 17 & 62.0 & $(\mathrm{CH})$ & 52.4 & $(\mathrm{CH})$ & 84.1 & (C) & 48.9 & $(\mathrm{CH})$ & 84.1 & (C) & 52.5 & $(\mathrm{CH})$ \\
\hline 18 & 13.8 & $\left(\mathrm{CH}_{3}\right)$ & 12.1 & $\left(\mathrm{CH}_{3}\right)$ & 14.9 & $\left(\mathrm{CH}_{3}\right)$ & 11.6 & $\left(\mathrm{CH}_{3}\right)$ & 15.0 & $\left(\mathrm{CH}_{3}\right)$ & 11.9 & $\left(\mathrm{CH}_{3}\right)$ \\
\hline 19 & 17.3 & $\left(\mathrm{CH}_{3}\right)$ & 17.4 & $\left(\mathrm{CH}_{3}\right)$ & 17.3 & $\left(\mathrm{CH}_{3}\right)$ & 17.3 & $\left(\mathrm{CH}_{3}\right)$ & 18.7 & $\left(\mathrm{CH}_{3}\right)$ & 19.3 & $\left(\mathrm{CH}_{3}\right)$ \\
\hline 20 & 45.5 & $(\mathrm{CH})$ & 47.1 & $(\mathrm{CH})$ & 48.9 & $(\mathrm{CH})$ & 51.2 & $(\mathrm{CH})$ & 48.7 & $(\mathrm{CH})$ & 47.0 & $(\mathrm{CH})$ \\
\hline 21 & 180.0 & (C) & 181.5 & (C) & 180.5 & (C) & 176.2 & (C) & 178.8 & (C) & 181.2 & (C) \\
\hline 22 & 30.2 & $\left(\mathrm{CH}_{2}\right)$ & 30.7 & $\left(\mathrm{CH}_{2}\right)$ & 27.5 & $\left(\mathrm{CH}_{2}\right)$ & 68.4 & $(\mathrm{CH})$ & 27.4 & $\left(\mathrm{CH}_{2}\right)$ & 31.9 & $\left(\mathrm{CH}_{2}\right)$ \\
\hline 23 & 32.2 & $\left(\mathrm{CH}_{2}\right)$ & 32.0 & $\left(\mathrm{CH}_{2}\right)$ & 32.1 & $\left(\mathrm{CH}_{2}\right)$ & 41.2 & $\left(\mathrm{CH}_{2}\right)$ & 32.0 & $\left(\mathrm{CH}_{2}\right)$ & 31.8 & $\left(\mathrm{CH}_{2}\right)$ \\
\hline 24 & 154.9 & (C) & 155.2 & (C) & 154.8 & (C) & 151.7 & (C) & 154.8 & (C) & 155.2 & (C) \\
\hline 25 & 33.7 & $(\mathrm{CH})$ & 33.8 & $(\mathrm{CH})$ & 33.7 & $(\mathrm{CH})$ & 33.5 & $(\mathrm{CH})$ & 33.8 & $(\mathrm{CH})$ & 33.7 & $(\mathrm{CH})$ \\
\hline 26 & 21.8 & $\left(\mathrm{CH}_{3}\right)$ & 21.8 & $\left(\mathrm{CH}_{3}\right)$ & 21.9 & $\left(\mathrm{CH}_{3}\right)$ & 21.9 & $\left(\mathrm{CH}_{3}\right)$ & 21.9 & $\left(\mathrm{CH}_{3}\right)$ & 21.8 & $\left(\mathrm{CH}_{3}\right)$ \\
\hline 27 & 21.7 & $\left(\mathrm{CH}_{3}\right)$ & 21.9 & $\left(\mathrm{CH}_{3}\right)$ & 21.7 & $\left(\mathrm{CH}_{3}\right)$ & 21.6 & $\left(\mathrm{CH}_{3}\right)$ & 21.7 & $\left(\mathrm{CH}_{3}\right)$ & 21.7 & $\left(\mathrm{CH}_{3}\right)$ \\
\hline 28 & 107.1 & $\left(\mathrm{CH}_{2}\right)$ & 107.0 & $\left(\mathrm{CH}_{2}\right)$ & 107.1 & $\left(\mathrm{CH}_{2}\right)$ & 110.5 & $\left(\mathrm{CH}_{2}\right)$ & 107.1 & $\left(\mathrm{CH}_{2}\right)$ & 106.8 & $\left(\mathrm{CH}_{2}\right)$ \\
\hline
\end{tabular}

a) Spectra recorded at $125 \mathrm{MHz}$ in $\mathrm{CDCl}_{3}$. b) $75 \mathrm{MHz}$ in $\mathrm{CDCl}_{3}$. c) Attached protons were deduced by DEPT experiments. 
at $\delta_{\mathrm{C}} 199.5(\mathrm{C}), 171.0(\mathrm{C}), 124.0(\mathrm{CH}), 38.5(\mathrm{C}), 35.6\left(\mathrm{CH}_{2}\right)$, and $33.9\left(\mathrm{CH}_{2}\right)$, and the UV absorption at $242 \mathrm{~nm}, \mathbf{1}$ was elucidated to contain an $\alpha, \beta$-unsaturated carbonyl structural unit in ring A. ${ }^{5}$ The presence of a carboxy group was also determined from the IR spectra $\left(1708 \mathrm{~cm}^{-1}\right)$ and ${ }^{13} \mathrm{C}$ chemical shifts $\left(\delta_{\mathrm{C}}\right.$ 180.0). Careful analysis of the ${ }^{1} \mathrm{H}-{ }^{1} \mathrm{H}$ COSY and HMBC spectra (Fig. 1) allowed us to determine the position of the hydroxy and the carbroxy group to be at C-16 and C20 , respectively. Detailed analysis of the ${ }^{1} \mathrm{H}-{ }^{1} \mathrm{H}$ COSY and HMBC correlations (Fig. 1) further established the planar structure of 1. In the NOESY spectrum of 1 (Fig. 2), the NOE correlations between $\mathrm{H}-16$ and $\mathrm{H}_{3}-18, \mathrm{H}-20$, and $\mathrm{H}-22$ ( $\delta 1.94$ ) as well as between $\mathrm{H}-8$ and both $\mathrm{H}_{3}-18$ and $\mathrm{H}_{3}-19$ indicated that these protons adapt a $\beta$-orientation. This was further supported comparing them to NOE correlations displayed between the protons at C-16, C-18, and C-20 of some known compounds. ${ }^{6}$ On the basis of above findings and other detailed NOE correlations, the structure of $\mathbf{1}$ was fully established as a rarely found 21-carboxysteroid. ${ }^{7-9}$

Chabrolosteroid E (2) was also obtained as a white powder. The HR-ESI-MS $\left(m / z\right.$ 427.3209, $\left.[\mathrm{M}+\mathrm{H}]^{+}\right)$and NMR data of 2 indicated a molecular formula of $\mathrm{C}_{28} \mathrm{H}_{42} \mathrm{O}_{3}$. Its UV $\left(\lambda_{\max } 240 \mathrm{~nm}, \log \varepsilon 3.77\right)$, IR $\left(v_{\max } 1674 \mathrm{~cm}^{-1}\right)$, and ${ }^{1} \mathrm{H}$ and ${ }^{13} \mathrm{CNMR}$ data (Tables 1 and 2 ) are very similar to those of 1 except that the NMR signals of H-16 and C-16 were shifted significantly upfield (from $\delta_{\mathrm{H}} 4.14$ to 1.90 and $1.32 \mathrm{ppm}$ and from $\delta_{\mathrm{C}} 75.8$ to $27.2 \mathrm{ppm}$, respectively) when compared to those of $\mathbf{1}$. This result showed the hydroxymethine at C-16 in $\mathbf{1}$ was replaced by a methylene in $\mathbf{2}$. These observations were further confirmed with the assistance of $2 \mathrm{D} \mathrm{NMR}\left({ }^{1} \mathrm{H}-\right.$ ${ }^{1} \mathrm{H}$ COSY and HMBC) experiments and by comparing of the NMR data to those of a known compound. ${ }^{7}$ From these results, $\mathbf{2}$ was the 16-deoxy derivative of $\mathbf{1}$.

Chabrolosteroid F (3) was found to possess the same molecular formula, $\mathrm{C}_{28} \mathrm{H}_{42} \mathrm{O}_{4}$, as that of $\mathbf{1}$ based on the HR-ESI-MS $\left(m / z 443.3163[\mathrm{M}+\mathrm{H}]^{+}\right)$and NMR data (Tables 1 and 2$)$. The ${ }^{1} \mathrm{H}$ and ${ }^{13} \mathrm{C}$ NMR spectral data of $\mathbf{3}$ are similar to those of $\mathbf{2}$ and showed the presence of an additional hydroxy group as compared to $\mathbf{2}$. Confirmation for the position of the hydroxy group at $\mathrm{C}$-17 came from $\mathrm{HMBC}$ correlations observed from $\mathrm{H}-14\left(\delta_{\mathrm{H}} 1.74, \mathrm{~m}\right), \mathrm{H}_{2}-16\left(\delta_{\mathrm{H}} 1.78, \mathrm{~m}\right), \mathrm{H}_{3}-18\left(\delta_{\mathrm{H}} 0.85, \mathrm{~s}\right)$, and $\mathrm{H}-20\left(\delta_{\mathrm{H}} 2.59, \mathrm{~m}\right)$ to $\mathrm{C}-17\left(\delta_{\mathrm{C}} 84.1, \mathrm{C}\right)$. The relative stereochemistry of compound $\mathbf{3}$ was established by comparing the NOESY correlations to those of $\mathbf{2}$. The NOE interactions observed between $\mathrm{H}_{3}-18$ and $\mathrm{H}-20$ confirmed that there is an $\alpha$-hydroxy at C-17. Moreover, the $\alpha$-orientation of $17-\mathrm{OH}$ was further confirmed by the lower field chemical shift of $\mathrm{H}$ $14\left(\delta_{\mathrm{H}} 1.74, \mathrm{~m}\right)$. On the basis of the above results, the structure of compound 3 was established.

Chabrolosteroid G (4) was found to be more polar than compounds 1-3 and was isolated as a white powder. It possessed the same molecular formula $\left(\mathrm{C}_{28} \mathrm{H}_{42} \mathrm{O}_{4}\right)$ as those of $\mathbf{1}$ and $\mathbf{3}$ as determined from HR-ESI-MS. The UV $\left(\lambda_{\max } 242 \mathrm{~nm}\right.$, $\log \varepsilon$ 3.91), and IR $\left(\nu_{\max } 1684 \mathrm{~cm}^{-1}\right)$ absorptions suggested the presence of an $\alpha, \beta$-unsaturated carbonyl system in 4 . Comparison of the ${ }^{1} \mathrm{H}$ and ${ }^{13} \mathrm{C} \mathrm{NMR}$ data (Tables 1 and 2) of both compounds showed that the structure of $\mathbf{4}$ should be very close to that of 2 , except for the signals assigned to $\mathrm{C}-22$, where a methylene $\left(\delta_{\mathrm{H}} 1.72,2 \mathrm{H}, \mathrm{m} ; \delta_{\mathrm{C}} 30.7\right)$ in 2 was replaced by a
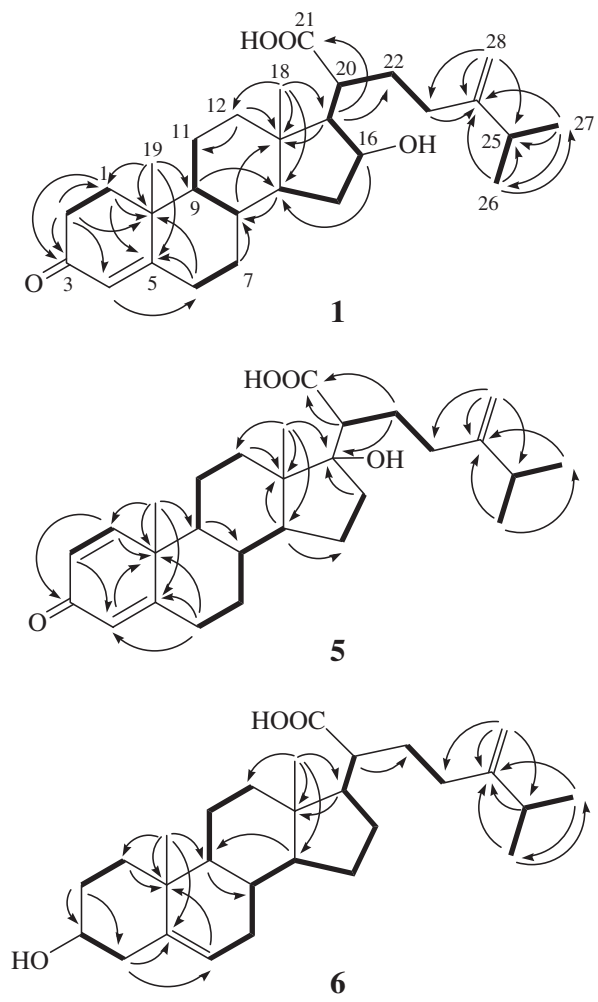

$$
=:{ }^{1} \mathrm{H}-{ }^{1} \mathrm{H} \operatorname{COSY}
$$

Fig. 1. Selective ${ }^{1} \mathrm{H}-{ }^{1} \mathrm{H}$ COSY and HMBC correlations for $\mathbf{1}, \mathbf{5}$, and $\mathbf{6}$.

hydroxymethine $\left(\delta_{\mathrm{H}} 3.89,1 \mathrm{H}\right.$, br s; $\left.\delta_{\mathrm{C}} 68.4\right)$ in 4 . The observed COSY between $\mathrm{H}-22$ and $\mathrm{H}_{2}-23$ and $\mathrm{HMBC}$ correlation between $\mathrm{H}_{2}-23$ to $\mathrm{C}-22$ and $\mathrm{C}-20$ further confirmed that a hydroxy group is present at C-22 location of the hydroxy group. Thus, $\mathbf{4}$ is the 22-hydroxy derivative of 2 .

Chabrolosteroid $\mathrm{H}(5)$ had a molecular formula of $\mathrm{C}_{28} \mathrm{H}_{40} \mathrm{O}_{4}$ as determined by HR-ESI-MS. The NMR signals appearing at $\delta_{\mathrm{H}} 7.04 / \delta_{\mathrm{C}} 151.6 ; 6.24 / 127.4 ; 6.10 / 123.8 ; 186.6$ (C) 169.7 (C), the IR absorption at $1658 \mathrm{~cm}^{-1}$, and $\mathrm{UV}$ maximum at $248 \mathrm{~nm}$ were assigned to a cross-conjugated dienone system by comparing to similar metabolites. ${ }^{10}$ Furthermore, the proton sequence from $\mathrm{H}-1$ to $\mathrm{H}-2$ and the $\mathrm{HMBC}$ spectrum (Fig. 1) showed long range correlations from $\mathrm{H}-1$ to $\mathrm{C}-3, \mathrm{C}-5, \mathrm{C}-10$; $\mathrm{H}-2$ to $\mathrm{C}-4$; H-4 to $\mathrm{C}-10$ and $\mathrm{H}_{3}-19$ to $\mathrm{C}-1, \mathrm{C}-5, \mathrm{C}-9, \mathrm{C}-10$, further supporting this structural unit in the A ring of $\mathbf{5}$. It was found that the remaining partial structures, including rings $\mathrm{B}, \mathrm{C}$, and D, and the side chain of $\mathbf{5}$, are identical to those of $\mathbf{3}$ by comparison of the related $1 \mathrm{D}\left({ }^{1} \mathrm{H}\right.$ and $\left.{ }^{13} \mathrm{C}\right)$ and $2 \mathrm{DNMR}$ data, particularly the ${ }^{1} \mathrm{H}-{ }^{1} \mathrm{H}$ COSY and HMBC correlations. Therefore, the structure of steroid $\mathbf{5}$ was established as the 1,2-dehydro derivative of 3.

The related metabolite, chabrolosteroid I (6), had a molecular formula $\mathrm{C}_{28} \mathrm{H}_{44} \mathrm{O}_{3}$ as indicated by the HR-ESI-MS $(\mathrm{m} / z$ 429.3365, $[\mathrm{M}+\mathrm{H}]^{+}$) and NMR data (Tables 1 and 2). The interpretation of the ${ }^{1} \mathrm{H}-{ }^{1} \mathrm{H}$ COSY and HMBC correlations (Fig. 1) were employed to determine the positions of the hydroxy, one double bond in the ring, and the carboxyl group to be at C-3, C-5/C-6, and C-20, respectively. Thus, the 


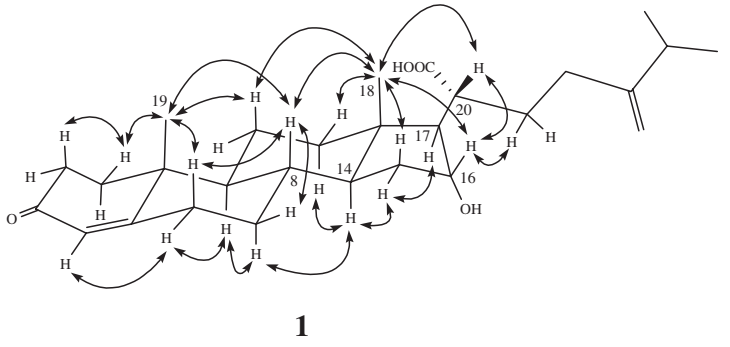

1

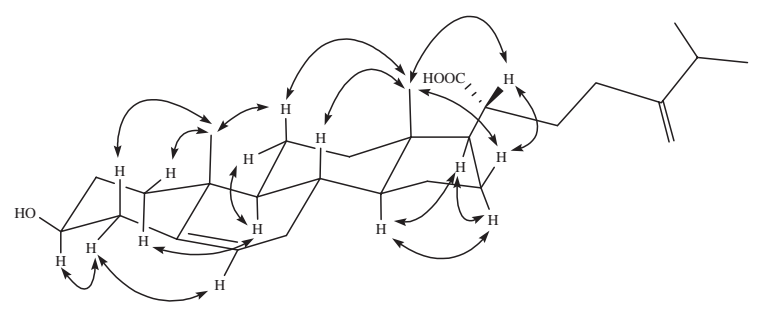

6

Fig. 2. Selective NOESY correlations for $\mathbf{1}$ and $\mathbf{6}$.

planar structure of $\mathbf{6}$ was established. The stereochemistry of 6 was further determined by analyzing the NOESY correlations (Fig. 2). Moreover, a comparison of the NMR data between 6 and 2 confirmed that in both compounds, rings $\mathrm{C}$ and $\mathrm{D}$ as well as the side chain have the same structure. On the basis of above analysis, the structure of $\mathbf{6}$ was unambiguously established. Compounds $\mathbf{2}$ and $\mathbf{6}$ did not possess a hydroxy group at both D-ring and side chain, and the other steroids (1 and 3-5) were found to be the rarely discovered 21carboxysteroids with hydroxy groups at C-16, C-17, or C-22, respectively.

The cytotoxicity of compounds 1-6 against the proliferation of a limited panel of cancer cell lines, including human hepatocellular carcinomas (Hep G2 and Hep 3B), human breast carcinomas (MCF-7 and MDA-MB-231), and a human lung carcinoma (A-549), was studied. The results showed that 1-5 are not cytotoxic toward the above cancer cells. Metabolite $\mathbf{6}$ exhibited a moderate to weak cytotoxicity toward Hep 3B $\left(\mathrm{IC}_{50} 15.6 \mu \mathrm{g} \mathrm{mL}^{-1}\right.$ ) and $\mathrm{A}-549\left(\mathrm{IC}_{50} 17.8 \mu \mathrm{g} \mathrm{mL}^{-1}\right.$ ) cancer cell lines.

\section{Experimental}

General Experimental Procedures. The IR spectra were recorded on a Jasco FT-5300 infrared spectrophotometer. UV spectra were recorded on a Hitachi U-3210 UV spectrophotometer. NMR spectra were recorded on a Bruker AVANCE DPX300 FT-NMR at $300 \mathrm{MHz}$ for ${ }^{1} \mathrm{H}$ and $75 \mathrm{MHz}$ for ${ }^{13} \mathrm{C}$ or on a Varian Unity INOVA $500 \mathrm{FT}-\mathrm{NMR}$ at $500 \mathrm{MHz}$ for ${ }^{1} \mathrm{H}$ and $125 \mathrm{MHz}$ for ${ }^{13} \mathrm{C}$, in $\mathrm{CDCl}_{3}$. Low-resolution MS data were obtained by ESI on a Bruker APEX II mass spectrometer. HRMS were recorded on ESI on a Bruker APEX II mass spectrometer. Silica gel (Merck, 230400 mesh) was used for column chromatography. High-performance liquid chromatography (HPLC) was performed on a Hitachi L-7100 apparatus equipped with a Bischoff refractive index detector, or a Hitachi L-7400 UV detector and with the Merck Hibar Si-60 column $(250 \times 21 \mathrm{~mm}, 7 \mu \mathrm{m})$.

Animal Material. The soft coral $N$. chabrolii was collected by hand using SCUBA off the coast of Pingtung County, located in southern Taiwan, in July 2001, at depths of $15-20 \mathrm{~m}$ and stored in a freezer until extraction. A voucher sample (SC-64) was deposited at the Department of Marine Biotechnology and Resources, National Sun Yat-sen University.

Extraction and Isolation. The sliced bodies of $N$. chabrolii $(1.8 \mathrm{~kg}$, wet wt) were exhaustively homogenized with $\mathrm{EtOH}$ and filtered. The combined EtOH extract was concentrated in vacuo to afford a dark brown viscous residue $(20.8 \mathrm{~g})$. The residue was triturated with $n$-hexane to afford an $n$-hexane soluble fraction, and then with EtOAc. The solvent was removed from the EtOAc soluble fraction under vacuum to yield an oily residue $(15.8 \mathrm{~g})$, which was subjected to column chromatography on silica gel, using $n$-hexane, $n$-hexane and EtOAc mixtures of increasing polarity, and finally pure EtOAc, to yield 28 fractions. Fraction 17 , eluted with $n$-hexane-EtOAc (2:1), was further separated by normal phase HPLC using $n$-hexane-acetone (5:1) to yield 2 $(4.7 \mathrm{mg})$ and $\mathbf{6}(5.0 \mathrm{mg})$. Fraction 21 , eluted with $n$-hexane-EtOAc (1:1), was further purified by normal phase HPLC using $n$ hexane-acetone (4:1) to afford $\mathbf{1}(5.7 \mathrm{mg}), \mathbf{3}(8.7 \mathrm{mg}), \mathbf{4}(2.1 \mathrm{mg})$, and $\mathbf{5}(2.2 \mathrm{mg})$, respectively.

Chabrolosteroid D (1): white powder; mp $181-184^{\circ} \mathrm{C} ;[\alpha]_{\mathrm{D}}^{25}=$ +50 ( $\left.c 1.14, \mathrm{CHCl}_{3}\right)$; UV (MeOH) $\lambda_{\max }(\log \varepsilon) 242$ (3.79) nm; IR (neat) $v_{\max } 3366,2935,1708,1680,1386 \mathrm{~cm}^{-1} ;{ }^{1} \mathrm{H} \mathrm{NMR}\left(\mathrm{CDCl}_{3}\right.$, $500 \mathrm{MHz})$ and ${ }^{13} \mathrm{CNMR}\left(\mathrm{CDCl}_{3}, 125 \mathrm{MHz}\right)$, see Tables 1 and 2; EI-MS $m / z, 442\left(8,[\mathrm{M}]^{+}\right.$); HR-ESI-MS $m / z, 443.3158$ (calcd for $\left.\mathrm{C}_{28} \mathrm{H}_{43} \mathrm{O}_{4}, 443.3163\right)$.

Chabrolosteroid E (2): white powder; mp $179-181^{\circ} \mathrm{C} ;[\alpha]_{\mathrm{D}}^{25}=$ +59 (c 1.00, $\left.\mathrm{CHCl}_{3}\right) ; \mathrm{UV}(\mathrm{MeOH}) \lambda_{\max }(\log \varepsilon) 240$ (3.77) nm; IR (neat) $v_{\max } 3378,2930,1706,1674,1379 \mathrm{~cm}^{-1} ;{ }^{1} \mathrm{HNMR}\left(\mathrm{CDCl}_{3}\right.$, $300 \mathrm{MHz})$ and ${ }^{13} \mathrm{CNMR}\left(\mathrm{CDCl}_{3}, 75 \mathrm{MHz}\right)$, see Tables 1 and 2; ESI-MS $m / z 427\left(100,[\mathrm{M}+\mathrm{H}]^{+}\right)$; HR-ESI-MS $m / z \quad 427.3209$ (calcd for $\mathrm{C}_{28} \mathrm{H}_{43} \mathrm{O}_{3}, 427.3214$ ).

Chabrolosteroid F (3): white powder; mp $185-187^{\circ} \mathrm{C} ;[\alpha]_{\mathrm{D}}^{25}=$ +47 (c 1.74, $\left.\mathrm{CHCl}_{3}\right)$; UV (MeOH) $\lambda_{\max }(\log \varepsilon) 240$ (3.82) nm; IR (neat) $v_{\max } 3420,2939,1703,1680,1380 \mathrm{~cm}^{-1} ;{ }^{1} \mathrm{H} \mathrm{NMR}\left(\mathrm{CDCl}_{3}\right.$, $500 \mathrm{MHz})$ and ${ }^{13} \mathrm{CNMR}\left(\mathrm{CDCl}_{3}, 125 \mathrm{MHz}\right)$, see Tables 1 and 2; ESI-MS $m / z 443\left(100,[\mathrm{M}+\mathrm{H}]^{+}\right)$; HR-ESI-MS $m / z 443.3163$ (calcd for $\mathrm{C}_{28} \mathrm{H}_{43} \mathrm{O}_{4}, 443.3163$ ).

Chabrolosteroid G (4): white powder; mp $190-192{ }^{\circ} \mathrm{C} ;[\alpha]_{\mathrm{D}}^{25}=$ +84 (c 1.00, $\left.\mathrm{CHCl}_{3}\right)$; UV (MeOH) $\lambda_{\max }(\log \varepsilon) 242$ (3.91) nm; IR (neat) $v_{\max } 3422,2929,1716,1684,1338 \mathrm{~cm}^{-1} ;{ }^{1} \mathrm{H} \mathrm{NMR}\left(\mathrm{CDCl}_{3}\right.$, $500 \mathrm{MHz})$ and ${ }^{13} \mathrm{CNMR}\left(\mathrm{CDCl}_{3}, 125 \mathrm{MHz}\right)$, see Tables 1 and 2; ESI-MS $m / z 465\left(80,[\mathrm{M}+\mathrm{Na}]^{+}\right)$; HR-ESI-MS $m / z, 465.2978$ (calcd for $\mathrm{C}_{28} \mathrm{H}_{42} \mathrm{O}_{4} \mathrm{Na}, 465.2980$ ).

Chabrolosteroid $\mathrm{H} \mathrm{(5):} \mathrm{white} \mathrm{powder;} \mathrm{mp} 188-190^{\circ} \mathrm{C} ;[\alpha]_{\mathrm{D}}^{25}=$ +37 (c 0.80, $\left.\mathrm{CHCl}_{3}\right)$; UV (MeOH) $\lambda_{\max }(\log \varepsilon) 248(3.90) \mathrm{nm}$; IR (neat) $v_{\max } 3423,2935,1714,1658,1361 \mathrm{~cm}^{-1} ;{ }^{1} \mathrm{H} \mathrm{NMR}\left(\mathrm{CDCl}_{3}\right.$, $500 \mathrm{MHz})$ and ${ }^{13} \mathrm{CNMR}\left(\mathrm{CDCl}_{3}, 125 \mathrm{MHz}\right)$, see Tables 1 and 2; ESI-MS $m / z 441\left(100,[\mathrm{M}+\mathrm{H}]^{+}\right)$; HR-ESI-MS $m / z, 441.3004$ (calcd for $\mathrm{C}_{28} \mathrm{H}_{41} \mathrm{O}_{4}, 441.3005$ ).

Chabrolosteroid I (6): white powder; mp 204-207 ${ }^{\circ} \mathrm{C} ;[\alpha]_{\mathrm{D}}^{25}=$ -77 (c 0.94, $\mathrm{CHCl}_{3}$ ); IR (neat) $v_{\max } 3420,2934,1699,1643$, $1377 \mathrm{~cm}^{-1}$; ${ }^{1} \mathrm{HNMR}\left(\mathrm{CDCl}_{3}, 500 \mathrm{MHz}\right)$ and ${ }^{13} \mathrm{C} \mathrm{NMR}\left(\mathrm{CDCl}_{3}\right.$, $125 \mathrm{MHz})$, see Tables 1 and 2; ESI-MS $m / z 429\left(100,[\mathrm{M}+\mathrm{H}]^{+}\right)$; HR-ESI-MS $m / z 429.3365$ (calcd for $\mathrm{C}_{28} \mathrm{H}_{45} \mathrm{O}_{3}, 429.3371$ ).

Cytotoxicity Testing. Cytotoxicity assays of compounds 1-6 were performed using the MTT [3-(4,5-dimethylthiazol-2-yl)-2,5diphenyltetrazolium bromide] colorimetric method. ${ }^{11}$

Financial support was provided by Ministry of Education (No. C030313) and National Science Council of Taiwan (No. NSC 95-2113-M-110-011-MY3) awarded to J.-H. Sheu. 


\section{References}

1 J.-H. Sheu, J.-H. Su, P.-J. Sung, G.-H. Wang, C.-F. Dai, J. Nat. Prod. 2004, 67, 2048.

2 J.-H. Su, A. F. Ahmed, P.-J. Sung, Y.-C. Wu, J.-H. Sheu, J. Nat. Prod. 2005, 68, 1651.

3 J.-H. Su, C.-F. Dai, H.-H. Huang, Y.-C. Wu, P.-J. Sung, C.-H. Hsu, J.-H. Sheu, Chem. Pharm. Bull. 2007, 55, 594.

4 J.-H. Su, F.-Y. Lin, H.-C. Huang, C.-F. Dai, Y.-C. Wu, W.-P. Hu, C.-H. Hsu, J.-H. Sheu, Tetrahedron 2007, 63, 703.

5 J.-M. Oger, P. Richomme, J. Bruneton, H. Guinaudeau, T. Sevenet, C. Debitus, J. Nat. Prod. 1991, 54, 273.
6 J. Saez, W. Cardona, D. Espinal, S. Blair, J. Mesa, M. Bocar, A. Jossang, Tetrahedron 1998, 54, 10771.

7 A. F. Ahmed, M.-H. Wu, Y.-C. Wu, C.-F. Dai, J.-H. Sheu, J. Chin. Chem. Soc. 2006, 53, 489.

8 M. Kobayashi, B. Haribabu, V. Anjaneyulu, Chem. Pharm. Bull. 1992, 40, 233.

9 J. R. Carney, W. Y. Yoshida, P. J. Scheuer, J. Org. Chem. 1992, 57, 6637.

10 C.-Y. Duh, A. H. El-Gamal, P.-Y. Song, S.-K. Wang, C.-F. Dai, J. Nat. Prod. 2004, 67, 1650.

11 T. Mosmann, J. Immunol. Methods 1983, 65, 55. 